\title{
CHALLENGES TO THE UTILIZATION OF INFORMATION AND COMMUNICATION TECHNOLOGY BY ENTREPRENEURS IN SOUTH-EAST, NIGERIA
}

\begin{abstract}
OKEKE NKECHI MERCY ${ }^{1}$, UZOAMAKA LUCYNDA KOLEDOYE ${ }^{2}$, JUSTINA NGOZI IGWE ${ }^{3 *}$, ANN EBERE OKECHUKWU ${ }^{4}$, BEATRICE N. ONAH ${ }^{5}$, POLYCARP M.D. OKEKE ${ }^{6}$, IHEANYICHUKWU G. OZURUMBA $^{7}$, STELLA CHIOMA NWIZU ${ }^{8}$, NWAKAEGO EBELE EKWEALOR ${ }^{9}$, KANU CATHERINE CHIUGO ${ }^{10}$
\end{abstract}

${ }_{1,2,3,4,5,6,7,8,9}$ Department of Adult Education and Extra-Mural Studies, University of Nigeria Nsukka, Enugu State, Nigeria

${ }^{10}$ Department of Business Education, Faculty of Vocational and Technical Education, University of Nigeria, Nsukka, Nigeria

\begin{abstract}
This study was aimed at determining the challenges to utilization of Information and Communication Technology by entrepreneurs in South-East, Nigeria. One research question was posed to identify the challenges to utilization of ICT by entrepreneurs in South-East, Nigeria. One null hypothesis tested at 0.05 level of significance guided the study. The design used for the study was descriptive survey and the instrument was structured questionnaire. The population of the study was all the 1251 registered entrepreneurs of medium and large scale enterprises in the private sector, from which a sample of 723 respondents were drawn using proportionate stratifies random sampling technique. Mean and standard deviation were used in analyzing the data collected from the research question and real limit of numbers was used to judge the responses as to whether they were high or low. The t-test statistics were used to test the hypothesis. Findings of the study showed that there are challenges to a high extent in utilization of ICT by entrepreneurs in South-East, Nigeria. The null hypothesis of no significant difference in challenges was not rejected. Based on the findings, recommendations were made which include that government should establish policies which induce reductions in the general burden of regulation, taxation and cost of internet access to spur entrepreneurs on the use of ICT in their enterprises, government should ensure regular power supply to entrepreneurs to reduce the cost of much use of generator, government should make computer education compulsory at all levels of education to make more members of the society ICT compliant and entrepreneurs should organize regular ICT courses for their staff to upgrade their knowledge of new technology.
\end{abstract}

KEYWORDS: Information and Communication, ICT \& Entrepreneurs

Received: Jun 10, 2020; Accepted: Jun 30, 2020; Published: Jul 16, 2020; Paper Id.: IJMPERDJUN2020352

\section{INTRODUCTION}

Importance of new technology - information and communication technology (ICT) is forcing entrepreneurs to tap technological knowledge so that they can measure up with the competition in the global market.According to Chris (2012) the growth of personal computer and computer networks continues to impact businesses both large and medium. Through computer and internet connection entrepreneurs can perform administrative tasks like paying your business bills on your computer, as well as marketing your business online, e-mail and instant messaging allow for easy communication. Moreover Uchegbu (2002) pointed out that the introduction and use of internet has caused an important revolution in communication and that is capable of improving the way we communicate, study, contract and transact business. This progress in business is noted as a result of progress in the ability to link up computers. 
Despite these obvious advantages opinions from the background of this study still show that entrepreneurs are not yet taping the benefits of ICT in enhancing their skills. These are however opinions and there is need to verify the authenticity of the opinions. Furthermore, Love and Irani (2001) said that enterprises could often experience barriers through lack of human technological resources needed for ICT and e-commerce. Especially when enterprises have to focus on day-to-day operations and lack the time and extra resources necessary to understand the benefits of new technologies. Even if they are aware of the potential benefits of adopting ICT, they would still require know-how or qualified personnel to enhance entrepreneurial operations. They claimed that enterprises may also lack managerial understanding and skills for e-business. Successful integration of e-business requires many enterprises to restructure their business processes, to change organizational structures and to redefine their core competence and positions in value chain. The professional advice of Information Technology (IT) and e-business consultants could help them but enterprises may not easily have ready access to them because of their relatively high costs.

Jide (2009) has rightly pointed out that the disadvantages of lack of ICT skills need in Nigeria makes the need for ICT user, professionals and skills more crucial now than ever. The enormous disadvantages are hindering the effectiveness of ICT. Though digital literacy has become a necessity for all but it may be that majority in Nigeria lack basic ICT user skills. Agbonifoh (2006) has remarked that the word computer still elicits different reactions from managers of private enterprises. Each person's reaction depends on the degree of computer literacy. For those who are literate in computers, the term conjures a world of clamoring opportunities waiting to be explored. They see in the computer, not only opportunities for word processing without tears and do it yourself desktop publishing of leaflets, posters, pamphlets and books, but also an avenue for fast-paced world-wide communication on the world of information highway. Further, the computer offers opportunities for simple and complex analysis of data, massive information storage and retrieval and access to virtual libraries on world-wide web. While some managers are carrying on as though the computer is not meant for them, others still rely on manual typewriter, manual storage, retrieval and processing of data and files.

In the same way, Igwe (2005) portrayed two critical issues, confronting the utilization of ICT to be illiteracy and inadequate educational opportunities in Nigerian educational system. On the other hand Olubamise and Jide (2007) opined that communications quality is low and ICT penetration is still insufficient considering Nigerian's size and population, the cost of broadband is still a barrier, poverty, lack of awareness and access excludes the poor, rural dwellers and private enterprises from ICT. Even if a determined entrepreneur manages to survive, there is still the problem of finding a reliable e-commerce infrastructure that will safely and reliably handle the electronic transactions without viewing the seller from Nigeria as high risk. There have been limitations on what one can buy online. There are rigours associated with online shopping systems and the restrictions in the global market (Ovia,2007).

\section{RESEARCH QUESTION}

- What are the challenges to the utilization of ICT in enterprises by entrepreneurs of medium and large scale enterprises in South-East Nigeria?

\section{Hypothesis}

There is no significant difference in the mean rating of entrepreneurs of medium and large scale enterprises on the challenges to utilization of ICT in enterprises. 


\section{LITERATURE REVIEW}

\section{Challenges to Utilization of ICT}

Despite the benefits, of ICT numerous barriers exist that make it difficult for enterprises to embrace these new technologies. In agreement, OECD (2004) stated that:

For firms to adopt e-business and e-commerce strategies and tools, benefits must outweigh investment and maintenance costs. Commercial considerations and potential returns drive adoption. Beyond a certain level of connectivity such as personal computer, internet access, on-line information or marketing, not all enterprises will necessarily catch up with large firms. This is because e-commerce may not bring large benefits and enterprises will stay with traditional business processes.

Other challenges according to them include: the availability of ICT competencies within the firm, cost of appropriate interoperable small-firm systems, network infrastructure and internet-related services. Lack of reliable legal and regulatory differences also impede cross-border transactions. Policies that will affect the adoption and use of ebusiness strategies include those designed to expand and improve the quality of network infrastructure, legal and regulatory environment, foster technological diffusion and create a favourable business environment.

According to OECD (2002b) three common barriers include:

- Unsuitability for Business - Enterprises may not see the relevance of ICT to their business. This was the leading reason given by businesses for not engaging in e-commerce as found by a survey conducted by OECD in 2002 of enterprises with fewer than 250 employees in 19 European countries. Many may believe that their goods or services do not lend themselves to internet transactions. Enterprises will not take advantage of e-business unless the benefits outweigh the costs and justify establishing and maintaining the e-commerce system. Enterprises may find it difficult to set an e-business case applicable to them because of lack of time, information and knowledge. They may also wish to retain their current business model and avoid the risks associated with new investments and new business models or also be worried that existing customers will be turned off by the changes.

In the same vein Love and Irani (2001) stated that:

In some sectors such as construction and some small retailers, the view that internet e-commerce is unsuitable for their business is relatively strong. A study of 20 small construction contractors in Australia with 2-45 employees suggests that small firms in this industry have been not only slow but even reluctant to implement ICT for e-commerce. p.31.

Also Mehrtens, Cragg and Mills (2001) pointed out that:

some enterprise in transport services also consider that the internet does not suit their industry. A firm with 90 employees and an emphasis on personal contact with clients decided not to adopt the internet after a three month trial of a website. During the trial the company received few inquiries regarding possible e-mailing of an order. Very few of its regular customers had used the internet and some preferred receiving confirmation of their order via fax or telephone.p.20

- Costs of developing and maintaining e-business system: OECD maintain that enterprises are generally concerned about the costs of establishing and maintaining e-commerce systems since they often suffer from budget constraints and are less sure of the expected returns on such investments. Some enterprises cannot afford to adopt sophisticated ICT solutions such as web sites with a secure environment allowing credit card transactions. 
Outsourcing webpage design and updating are optional but the costs of such may be difficult for enterprises to contain. According to them logistics services, such as package collection and delivery also matter. This is a real concern for small businesses, especially in remote district where private package collection or delivery services may not be available at reasonable costs. Some items such as software, music and books could be delivered digitally but it may not be feasible for an individual business or customer with slow internet connections or small download capacities.

- Network Infrastructure: Other common barriers indicated by OECD is that lack of broadband connections may affect enterprises decisions to adopt e-commerce. Also slow internet connections and slow data transfers discourage enterprises adoption of the internet.

Besides, the UNDP (2007) indicated several barriers that prevent enterprises from implementing or maintaining ICT business. These barriers include:

- Enterprises lack of information on applicability of ICT, of human and financial resources for implementation and of broadband connections at competitive prices.

- Insecurities surrounding payments, contract, delivery, privacy and legal protections on both the business and the client side.

- Efforts to improve internet access in Africa have been hampered by a number of factors as identified by UNESCO (1998) as follows:

- The small number of potential users having both the skills and equipment to benefit from access to electronic information networks.

- The scarcity and high costs of equipment, software and information compared to situations in other countries.

- Lack of reliable and accessible physical telecommunications infrastructure.

- Telecommunications monopoly, associated with overly restrictive regulations and high costs.

- Lack of interregional networking and cooperation.

Also OECD (2003) stated that, for the information society to hold, one very serious battle to win is to enhance trust and confidence in ICT and networked systems. There are a number of threats to ICT use such as spam, virus attacks, worms, hacking, cracking, network outages, all of which affect operations, whether in businesses, homes, hospitals or critical infrastructures as a whole.

All companies, big corporations, SMEs or micro enterprises face the barriers when contemplating e-business implementation. These obstacles according to European Commission (2000) were grouped into six main categories:

- Management and strategy: Management Attitudes and Organizational Inflexibility can be more serious in enterprises because of traditional leadership and organizational forms. Firms operating in more traditional sectors also tend to be less innovative. However this is less of a problem in new companies where management may be more receptive to technology.

- 2. Cost and financing: The cost of implementation of e-business can be serious barriers for enterprises. The 
cost of setting up an e-business includes preliminary planning, procuring hardware or software tools, continuous maintenance, servicing costs and telecommunications charges.

- Skills and training: The lack of suitable technical and managerial staff with sufficient ICT expertise is another major barrier. Enterprises critically depend on on-the-job-competence.

- The supply chain: There needs to be shared conviction and full engagement in the technology, up and down the supply chain to ensure that the rewards can be achieved. Where software or systems prove to be incompatible with those of customers and suppliers, there is a high risk that ICT investment may be lost.

- Technology choices: The enterprises needs to have a system which is compatible to the systems used by large suppliers or customers who may have resources to implement complex IT solutions. The enterprise does not have that luxury.

- Security and reliability: Many enterprises are afraid to move to electronic systems because of the potential for theft of business information and funds, alteration of financial documents, as well as the potential for illicit transactions and concerns over payment security.

Many enterprises managers are so reluctant to change into ICT business even when they know the benefits. Economics failures could pose a serious constraint particularly in a fast-changing environment like the internet. Enterprises have a strong interest in standardized and fully compatible ICT solutions that stay relatively stable over time. The complexity and lack of robustness of many ICT solutions are discouraging many enterprises. It is this singular gap that the present study expects to fill.

\section{METHOD}

The study used descriptive survey research design. The area of study is South-East Zone of Nigeria comprising of the present Abia, Anambra, Enugu, Ebonyi and Imo States. The population is 1251 registered entrepreneurs of medium and large scale enterprise in South-East Zone of Nigeria. The sample is 723 entrepreneurs. Proportionate Stratified Sampling Technique was used to determine entrepreneurs of medium scale enterprises while the entire entrepreneurs of large scale enterprises were used. The instrument used was the questionnaire adapted from Global E-commerce Survey, 2002. The number of items in the questionnaire was 11.

The instrument was subjected to face validity by three experts. Their inputs were incorporated into the instrument by the researcher. The reliability of the instrument was established through field trial test by administering the instrument to 30 entrepreneurs outside the Zone of study. Cronbach Alpha was used to analyze the data. The reliability estimate was .81 which shows that the instrument is reliable. The researcher employed the services of eight research assistants for the five states.

Data were analyzed using mean and standard deviation to answer research question. In interpreting the response of entrepreneurs the real limit of numbers was adopted. The t-test statistics were used to test hypothesis at 0.05 level of significance. 


\section{RESULTS}

\section{Research Question}

What are the challenges to the utilization of ICT in enterprises in South-East, Nigeria?

Table 1: Mean Scores of Entrepreneurs of Medium and Large Scale Enterprises on the Challenges to the Utilization of ICT in Enterprises $(N=512)$

\begin{tabular}{|c|c|c|c|c|}
\hline $\mathbf{S} / \mathbf{N}$ & Item & $-\mathbf{X}$ & $\begin{array}{l}\text { Standard } \\
\text { Deviation }\end{array}$ & Decision \\
\hline 1. & $\begin{array}{l}\text { Lack of face to face interactions } \\
\text { discourages the internet buyers. }\end{array}$ & 2.52 & 1.09 & $\mathrm{HE}$ \\
\hline 2. & $\begin{array}{l}\text { Privacy of data or security issues affects } \\
\text { the confidence of customers in internet use. }\end{array}$ & 2.53 & .99 & $\mathrm{HE}$ \\
\hline 3. & $\begin{array}{l}\text { Customers incompetence in using the } \\
\text { technology limits their internet access. }\end{array}$ & 3.07 & .88 & $\mathrm{HE}$ \\
\hline 4. & $\begin{array}{l}\text { Limited number of competent staff affects } \\
\text { entrepreneurs in employment. }\end{array}$ & 3.14 & .90 & $\mathrm{HE}$ \\
\hline 5. & $\begin{array}{l}\text { Inadequate electric power supply increases } \\
\text { the cost of production and sales }\end{array}$ & 2.92 & .88 & HE \\
\hline 6. & $\begin{array}{l}\text { Lack of fund to purchase electronic } \\
\text { equipment weakens the entrepreneurs. }\end{array}$ & 2.80 & .93 & $\mathrm{HE}$ \\
\hline 7. & $\begin{array}{l}\text { Incompetence in the use of internet as part } \\
\text { of business strategydelays adoption of e- } \\
\text { business. }\end{array}$ & 2.74 & .93 & $\mathrm{HE}$ \\
\hline 8. & $\begin{array}{l}\text { High cost of internet access reduces the use } \\
\text { for both entrepreneurs and customers. }\end{array}$ & 2.88 & .85 & HE \\
\hline 9. & $\begin{array}{l}\text { None support of business laws for e- } \\
\text { commerce creates fear in the entrepreneurs. }\end{array}$ & 2.90 & .82 & $\mathrm{HE}$ \\
\hline 10. & $\begin{array}{l}\text { Taxation of internet sales increases the cost } \\
\text { of purchase. }\end{array}$ & 3.04 & .84 & $\mathrm{HE}$ \\
\hline \multirow[t]{2}{*}{11.} & $\begin{array}{l}\text { Inadequate legal protection for internet } \\
\text { purchases affects the interest of the } \\
\text { entrepreneurs. }\end{array}$ & 2.49 & 1.12 & $\mathrm{LE}$ \\
\hline & Grand Mean & 2.57 & 1.09 & HE \\
\hline
\end{tabular}

Table 1 shows that items 1,2,3.4,5,6,7,8,9 and 10 have their means ranging from $2.50-3.49$. This means that the identified challenges hinder entrepreneurs from using ICT to a high extent. Item 11 has its mean (2.49) within a range of $1.50-2.49$. It shows that inadequate legal protection of internet purchases hinders entrepreneurs from utilizing ICT to a low extent.

The grand means of 2.57 was obtained for the cluster, showing that the identified factors are challenges to the utilization of ICT in enterprises in the South-East, Nigeria to a high extent.

\section{H0}

There is no significant difference in the mean rating of entrepreneurs of medium and large scale enterprises on the challenges to utilization of ICT in enterprises. The data verifying the above hypothesis is presented in table two 
Table 2: T-Test of Difference between the Mean Scores of Entrepreneurs of Medium and Large scale Enterprises on the Challenges to Utilization of ICT in Enterprises in South-East, Nigeria

\begin{tabular}{|l|c|c|c|c|c|c|c|}
\hline Enterprises & $\mathbf{N}$ & $\mathbf{X}$ & SD & Df & T & $\begin{array}{c}\text { Sig } \\
\text { (2-tailed) }\end{array}$ & Decision \\
\hline Medium & 277 & 2.51 & 1.12 & 510 & -1.30 & .20 & \\
\hline Large & 235 & 2.64 & 1.05 & & & & Not Significant \\
\hline
\end{tabular}

Table 2 shows that the calculated t value -1.30 and significant 0.20 but not significant at 0.05 . This is because 0.20 is greater than 0.05 . The hypothesis was not rejected. Therefore there is no significant difference between the mean scores of entrepreneurs of medium and large scale enterprises on the challenges to utilization of ICT.

\section{DISCUSSIONS}

What are the challenges to utilization ofICT by entrepreneurs of medium and large scale enterprises in South-East, Nigeria?

The finding show that entrepreneurs of medium and large scale enterprises encounter challenges to a high extent in utilization of ICT in enterprises in the South-East Nigeria. The major challenges revealed were limited number of competent staff, customers incompetence in using technology, taxation of internet sales and inadequate electric power supply. The findings are not surprising because of the level of development in the economy which is depicted in the areas of lack of infrastructure, lack of fund and inadequate access to ICT facilities. The study lends credence to the findings of European Commission (2000) that many enterprises are afraid to move to electronic systems because of the incompetence, potential for theft of business information and funds, alteration of financial documents as well as the high cost of internet access. The result also is in line with the findings of UNDP (2007) which indicated that several barriers which prevent enterprises from maintaining ICT business include enterprise lack of information on applicability of ICT, human and financial resources, insecurity surrounding payments, delivery, privacy and legal protections on both the business and the client side.

\section{Hypothesis}

There is no significant difference in the mean rating of entrepreneurs of medium and large scale enterprises on challenges to utilization of ICT in enterprises.

Table 2 shows that the calculated t value -1.30 and significant at 0.20 but not significant at 0.05 . This is because 0.20 is greater than 0.05 . The hypothesis was not rejected. Therefore there is no significant difference between the mean scores of entrepreneurs of medium and large scale enterprises on the barriers to utilization of ICT in enterprises. The response of entrepreneurs agrees with OECD (2003) that for information society to hold, one very serious battle to win is to enhance trust and confidence in ICT and networked systems. There are a number of threats to ICT use such as spam; virus attacks; worms; hacking; cracking; network outages; all of which affect operations; whether in businesses; homes; hospitals or critical infrastructure.

\section{RECOMMENDATIONS}

- Government should establish policies which induce reductions in the general burden of regulation, taxation and cost of internet access to spur entrepreneurs on the use of ICT in their enterprises. 
- Government should ensure regular power supply to entrepreneurs to reduce the cost of much use of generator.

- Government should make computer education compulsory at all levels of education to make more members of the society ICT compliant.

- Entrepreneurs should organize regular ICT courses for their staff to upgrade their knowledge of new technology.

\section{CONCLUSIONS}

challenges to ICT utilization in enterprises are enormous but can also be eliminated. The solutions lies much on giving attention to the recommendations in this study. Entrepreneurs need a change of orientation in their business structure and minds set to queue into the global world.Insisting on old ways of running enterprises may still live them behind in the world of digital knowledge. Since no entrepreneur wants to remain behind, hence the urgent struggle to overcome every challenges to ICT utilization in enterprises should be adopted.

\section{REFERENCES}

1. Agbonifoh, B.A. (2006). Computer applications and the small business. Lagos: Malthouse press Lagos.

2. Chris, J. (2012) the impact of computers in small business. Pennsylvania: Yoke College.

3. European Commission. (2000). The current and future barriers to sme revolution. Retrieved August 17, 2007, from http://www.usherproject.org.uk/support/scenarios/.

4. Igwe, U.O. (2005). Harnessing information technology for the $21^{\text {st }}$ century: Library education in Nigeria, Library Philosophy and practice. Spring.Vol.7, No.2 Retrieved July 5, 2009, from http:libr.unl.edu.2000/lpp/igwe.htm.

5. Jide, A.C. (2009). Real Independence, Nigeria and ICT for development. Nigeria: Jide Systems Limited.

6. Moses, Chinonye, et al. "Entrepreneurship education and action-oriented pedagogical approaches." International Journal of Educational Science and Research 5.5 (2015): 53-60.

7. Love, P.E.D \&Irani, Z. (2001).An empirical analysis of the barriers to implementing e-commerce in small-medium sized construction contractors in the state of Victoria; Australia: Construction innovation.

8. Mehrtens, J., Cragg, P.B \& Mills, A.M. (2001).A model of internet adoption by SMEs .Information and Management. 39 , 165 -176 .

9. RAO, V. Venkateswara, and D. Pushpa Sri."The Role of Entrepreneurship Education in Nurturing the Potential Entreprenuers to Fuel The Economic Growth Engine-a Study. "International Journal of Business Management \& Research (IJBMR) 9. 1, Feb 2019, $13-22$

10. OECD.(2002b). Information Technology Outlook. Paris, OECD.

11. OECD. (2003). Information Society: The ICT challenges Retrieved April 4, 2007, from http://www.oecdobserver.org/news/fullstory.php/aid/1146/Information_society:_The_ICT_challenge.html

12. Gill, Mukti."Empowering Quality Higher Education using Information Technology."International Journal of Educational Science and Research (IJESR) 4. 6, Dec 2014, 9-14

13. OECD.(2004). ICT, E-business and SMEs Paris Cedex, France. Retrieved May 5, 2008, from http://www.oecd.org/dataoecd/32/28/34228733.pdf

14. Olubamise, B. \&Jide, A.C. (2007).A synopsis of the ICT4D sector in Nigeria incorporating activities of the government, 
private sector and non-governmental organizations. Lagos: Jidaw System Ltd.

15. Ovia, F. (2007).E-Commerce in Nigeria - What the future holds. Centre surlespolitiques internationals des TIC Africa du centreet de l'Quest. Retrieved March 10, 2011, from http://www.thisdayonline.com/nview

16. Uchegbu, S.N. (2002) Issues and strategies in environmental planning and management in Nigeria. Nigeria: Spotlite Publishers.

17. UNESCO. (1998). Harnessing information Technology for development in Africa. Retrieved May 5, 2008, from www.unesco.org/education/educprog/lwf/doc/IAI.html

18. Moses, Chinonye. "Entrepreneurship Education and Student's Life Challenging Situations: An Empirical Study of Covenant University, Ota, Ogun State, Nigeria." International Journal of Business and General Management (IJBGM) 3.4 (2014): 1-10.

19. UNDP .(2007). The role of government in promoting ICT access and use by SMEs considerations for public policy. Retrieved September 7, 2007, from http://www.apdi.net/apdipenote/12.pdf. 

